\title{
BENIGN POLYARTHRITIS*
}

BY

\section{J. S. LAWRENCE AND P. H. BENNETT}

From the Empire Rheumatism Council Field Unit, University of Manchester

In a recent survey of rheumatism in persons between the ages of 55 and 64 in an urban population (Kellgren and Lawrence, 1956), it was found that 36 out of the total 380 persons examined gave a past history of a transient inflammatory polyarthritis. Though carrying eventually a good prognosis, this form of polyarthritis was responsible for considerable incapacity at the time of the attack and it therefore seemed important that more information should be available on its nature and causes. Some of these patients had undoubted rheumatic fever, but there was no indication as to how many could justifiably be included in this category.

To study this and many other problems, the urban population survey mentioned above, was extended during the years 1956-59 to include all ages from 15 onwards.

\section{Method of Sampling}

In the 1956-59 survey, a 1 in 30 sample of households in the town of Leigh was used. The method of sampling was to pick from the electoral roll initially, every 360th household, giving a total of 42 houses. To these were added the inmates of the house five doors along in either direction, giving a total of 126 households. This method of "clustering", facilitated visiting without introducing factors which might arise from taking adjacent houses.

Each of the houses so chosen was visited by a medico-social worker following an initial explanatory letter and all those between the ages of 15 and 54 and from 65 onwards were invited to attend an $x$-ray centre which was set up in the school-hall. Those unable or unwilling to attend were examined by the physician at home when $x$ rays were taken by means of a portable set. Where the household had moved to another town since the last electoral roll was compiled, the new occupants of the house were substituted. When 85 per cent. of the initial

\footnotetext{
* Paper read to the Heberden Society in December, 1959.
}

sample had been examined, a new sample of 126 households was chosen and examined in the same way up to 85 per cent completion, and this was repeated till over 200 persons had been examined in each decade up to age 54 . The numbers in the older age groups were of course, smaller.

\section{Examination}

A history was taken of all symptoms, whether rheumatic or not, but particular attention was paid to incapacitating musculo-skeletal disorders. In capacity was graded according to the number of weeks lost from work. In the case of housewives of retired persons, confinement to the home was substituted. All those attending the centre were submitted to a detailed examination of the skeletal system and the blood pressure was taken. In those with a history of past polyarthritis, the heart was examined. In addition, in all persons a sample of blood was drawn for the sheep-cell test which was assessed by the method of Ball (1950). Radiographs were taken according to the following scheme, designed to reduce radiation genetic hazards to a minimum.

\begin{tabular}{c|c}
\hline Age (yrs) & Parts $x$-rayed \\
\cline { 2 - 3 }-34 & $\begin{array}{l}\text { Hands, feet, and cervical spine } \\
\text { Hands, feet, and cervical spine, lumbar } \\
\text { spine, and knees } \\
\text { Hands, feet, cervical and lumbar spine, } \\
\text { knees, and pelvis }\end{array}$ \\
\hline
\end{tabular}

Antero-posterior views only were taken of the hands, feet, knees, and pelvis, and lateral views only of the spine. During the first half of the survey, a routine $x$ ray of the chest and in the latter half, of the dorsal spine was included. The chest was 
$x$-rayed in those with a history of past polyarthritis throughout the survey.

\section{Completeness of Survey}

For the present studies, a 1 in 2 sample of persons between the ages of 55 and 64 from the 1954 survey, stratified by clinical rheumatoid grading, has been added to give a complete age range from 15 onwards. When these had been added to the total, the sample comprised 751 males and 814 females of whom 653 males and 690 females were $x$-rayed or had a blood test giving a completion rate of 87 and 85 per cent. respectively (Table I). Some of the remainder had a clinical examination only. These have not been included in assessing the completion rate.

\section{Prevalence}

A past history of polyarthritis was encountered in 34 males and fifty females, 5 and 7 per cent. respectively of the total examined in each sex (Table II). The proportion giving a history of this type rose with age in females but showed no constant age correlation in males. Seven males and fifteen females showed residual evidence of arthritis either clinically or radiologically in the form of erosive arthritis. Osteo-arthrosis was not included amongst the residua but will be considered later. Arthritic residua were thus encountered in 26 per cent. of persons with a history of polyarthritis. None of those below age 35 had residua, but above this age there was no striking relationship with age.

The clinical residua are analysed in detail in

TABLE I

COMPLETENESS OF SURVEY

\begin{tabular}{|c|c|c|c|c|c|c|c|c|}
\hline Sex & $\begin{array}{c}\text { Age } \\
\text { (yrs) }\end{array}$ & $\begin{array}{l}\text { Total in } \\
\text { Sample }\end{array}$ & $\begin{array}{l}\text { Not Available } \\
\text { or Refused All } \\
\text { Examination }\end{array}$ & $\begin{array}{c}\text { Total } \\
\text { Examined }\end{array}$ & $\begin{array}{c}\text { Completion } \\
\text { Rate } \\
\text { (per cent.) }\end{array}$ & $\begin{array}{c}\text { Clinical } \\
\text { Examination, } \\
X \text { Ray and } \\
\text { Blood Test }\end{array}$ & $\begin{array}{c}\text { Clinical } \\
\text { Examination, } \\
\text { and } X \text { Ray } \\
\text { Only }\end{array}$ & $\begin{array}{c}\text { Clinical } \\
\text { Examination, } \\
\text { and Blood Test } \\
\text { Only }\end{array}$ \\
\hline \multirow[t]{2}{*}{ Male } & \begin{tabular}{|c|}
-24 \\
-34 \\
-44 \\
-54 \\
-64 \\
-74 \\
$75+$ \\
Not stated
\end{tabular} & $\begin{array}{r}125 \\
131 \\
127 \\
169 \\
102 \\
65 \\
26 \\
6\end{array}$ & $\begin{array}{r}20 \\
12 \\
20 \\
18 \\
9 \\
10 \\
3 \\
6\end{array}$ & $\begin{array}{l}105 \\
119 \\
107 \\
151 \\
93 \\
55 \\
23\end{array}$ & $\begin{array}{l}83 \\
91 \\
84 \\
89 \\
91 \\
84 \\
88\end{array}$ & $\begin{array}{r}97 \\
112 \\
102 \\
147 \\
87 \\
50 \\
21\end{array}$ & $\begin{array}{l}1 \\
6 \\
4 \\
4 \\
5 \\
2 \\
1\end{array}$ & $\begin{array}{l}7 \\
1 \\
1 \\
0 \\
1 \\
3 \\
1\end{array}$ \\
\hline & Total .. & 751 & 98 & 653 & 87 & 616 & 23 & 14 \\
\hline \multirow[t]{2}{*}{ Female } & $\begin{array}{c}-24 \\
-34 \\
-44 \\
-54 \\
-64 \\
-74 \\
75+ \\
\text { Not stated }\end{array}$ & $\begin{array}{r}122 \\
115 \\
148 \\
171 \\
138 \\
81 \\
34 \\
5\end{array}$ & $\begin{array}{r}16 \\
9 \\
24 \\
19 \\
26 \\
18 \\
7 \\
5\end{array}$ & $\begin{array}{r}106 \\
106 \\
124 \\
152 \\
112 \\
63 \\
27\end{array}$ & $\begin{array}{l}86 \\
92 \\
84 \\
89 \\
81 \\
78 \\
79\end{array}$ & $\begin{array}{r}95 \\
98 \\
119 \\
139 \\
100 \\
53 \\
19\end{array}$ & $\begin{array}{r}3 \\
6 \\
5 \\
12 \\
11 \\
9 \\
3\end{array}$ & $\begin{array}{l}8 \\
2 \\
0 \\
1 \\
1 \\
1 \\
5\end{array}$ \\
\hline & Total $\ldots$ & 814 & 124 & 690 & 85 & 623 & 49 & 18 \\
\hline
\end{tabular}

N.B.-A number of persons aged 15-24 yrs had $x$ rays of the dorsal spine only. These are included in the last column (Clinical Examination and Blood Test Only) because their $\boldsymbol{x}$ rays were incomplete.

TABLE II

PREVALENCE OF PAST POLYARTHRITIS BY AGE AND SEX

\begin{tabular}{|c|c|c|c|c|c|c|c|c|c|c|c|c|}
\hline \multirow{4}{*}{$\begin{array}{c}\text { Age } \\
\text { (yrs) }\end{array}$} & \multicolumn{5}{|c|}{ Males } & \multicolumn{5}{|c|}{ Females } & \multirow{2}{*}{\multicolumn{2}{|c|}{$\frac{\text { Both }}{\text { Past Polyarthritis }}$}} \\
\hline & \multirow{3}{*}{$\begin{array}{l}\text { Total in } \\
\text { Sample }\end{array}$} & \multirow{3}{*}{$\underset{\text { Examined }}{\text { Total }}$} & \multicolumn{3}{|c|}{ Past Polyarthritis } & \multirow{3}{*}{$\begin{array}{l}\text { Total in } \\
\text { Sample }\end{array}$} & \multirow{3}{*}{$\begin{array}{c}\text { Total } \\
\text { Examined }\end{array}$} & \multicolumn{3}{|c|}{ Past Polyarthritis } & & \\
\hline & & & & Cotal & With & & & \multicolumn{2}{|c|}{ Total } & \multirow{2}{*}{$\begin{array}{l}\text { With } \\
\text { Residua }\end{array}$} & \multirow{2}{*}{ Total } & \multirow{2}{*}{$\begin{array}{c}\text { Percentage } \\
\text { with } \\
\text { Residua }\end{array}$} \\
\hline & & & No. & Per cent. & & & & No. & Per cent. & & & \\
\hline $\begin{array}{l}-24 \\
-34 \\
-44 \\
-54 \\
-64 \\
65+\end{array}$ & $\begin{array}{r}125 \\
131 \\
127 \\
169 \\
102 \\
91\end{array}$ & $\begin{array}{r}105 \\
119 \\
107 \\
151 \\
93 \\
78\end{array}$ & $\begin{array}{r}6 \\
4 \\
4 \\
6 \\
10 \\
4\end{array}$ & $\begin{array}{r}6 \\
3 \\
4 \\
4 \\
11 \\
5\end{array}$ & $\begin{array}{l}0 \\
0 \\
2 \\
0 \\
3 \\
2\end{array}$ & $\begin{array}{l}122 \\
115 \\
148 \\
171 \\
139 \\
115\end{array}$ & $\begin{array}{r}106 \\
106 \\
124 \\
152 \\
112 \\
90\end{array}$ & $\begin{array}{r}4 \\
5 \\
7 \\
13 \\
11 \\
10\end{array}$ & $\begin{array}{r}4 \\
5 \\
6 \\
9 \\
10 \\
11\end{array}$ & $\begin{array}{l}0 \\
0 \\
4 \\
3 \\
2 \\
6\end{array}$ & $\begin{array}{r}10 \\
9 \\
11 \\
19 \\
21 \\
14\end{array}$ & $\begin{array}{r}0 \\
0 \\
50 \\
16 \\
24 \\
71\end{array}$ \\
\hline Total .. & 745 & 653 & 34 & 5 & 7 & 753 & 690 & 50 & 7 & 15 & 84 & 26 \\
\hline
\end{tabular}


Table III, comparison being made with those persons in the sample who gave no history of polyarthritis. Clinical residua were found in 9 per cent. of males with a past history of polyarthritis but in only 2 per cent. of those without such a history. In females, the proportions were 24 per cent. and 4 per cent. respectively. Differences in age distribution could not account for these differences. Not only were clinical residua five times as common in those with a past history, but they appeared at an earlier age, the peak prevalence being at age 35 to 44 compared with a peak at age 55 to 64 in those without a history of past polyarthritis.

Clinical residua included subluxation in the interphalangeal and metatarsophalangeal joints, and pain or limitation of movement of the metacarpophalangeal joints, wrists, knees, tarsal joints, and cervical spine. One patient gave a history of recurrent tendon sheath swellings. Three patients had frank rheumatoid arthritis, but only one of these had a positive sheep-cell agglutination test.

Radiological residua (Table IV) were also more frequent in persons with a past history of poly- arthritis, particularly in the cervical spine, only slightly in the hands and feet. Indeed, there was radiological evidence of erosive arthritis in these sites in only three persons with a past history of polyarthritis. In no instance was there definite evidence of erosive arthritis in the sacro-iliac joints. The cervical changes (Figs 1 and 2, opposite) did not appear at an earlier age in those with past polyarthritis, none being found before age 45 . They differed somewhat in appearance from those encountered in persons with rheumatoid arthritis (Sharp, Purser, and Lawrence, 1958). Subluxation was a less striking feature and degenerative changes were more marked. These differed, however, from appearances in simple disk degeneration in that the upper cervical disks were affected more than the lower. There was no evidence of growth defect in the cervical spine and indeed, only two of those with cervical changes had their attack of polyarthritis before age 55 , so that cervical involvement would appear to be a feature mainly of late polyarthritis. No definite spondylitis was encountered in any of these persons with a history of polyarthritis.

TABLE III

CLINICAL RESIDUA OF INFLAMMATORY ARTHRITIS IN PERSONS WITH AND WITHOUT A PAST HISTORY OF POLYARTHRITIS, BY SEX AND AGE

\begin{tabular}{|c|c|c|c|c|c|c|c|c|c|c|c|c|c|c|c|c|c|}
\hline \multirow{4}{*}{$\begin{array}{l}\text { Age } \\
\text { (yrs) }\end{array}$} & & & & & \multicolumn{5}{|l|}{ Males } & \multicolumn{7}{|c|}{ Females } & \\
\hline & \multicolumn{4}{|c|}{ Past Polyarthritis } & \multicolumn{5}{|c|}{ No Past Polyarthritis } & \multicolumn{4}{|c|}{ Past Polyarthritis } & \multirow{2}{*}{\multicolumn{3}{|c|}{ No Past Polyarthritis }} & \\
\hline & \multirow{2}{*}{ Total } & \multicolumn{2}{|c|}{ Grade } & \multirow{2}{*}{$\underset{2-4}{G r a d e}$} & \multirow{2}{*}{ Total } & \multicolumn{3}{|c|}{ Grade } & \multirow{2}{*}{$\underset{2-4}{\text { Grade }}$} & \multirow{2}{*}{ Total } & \multicolumn{2}{|c|}{ Grade } & \multirow{2}{*}{$\underset{2-4}{\text { Grade }}$} & & & & \multirow{2}{*}{ Grade } \\
\hline & & 01 & $\begin{array}{lll}2 & 3 & 4\end{array}$ & & & 01 & 23 & 4 & & & 01 & 234 & & Total & 01 & 234 & \\
\hline $\begin{array}{l}-24 \\
-34 \\
-44 \\
-54 \\
-64 \\
65+\end{array}$ & $\begin{array}{r}6 \\
4 \\
4 \\
6 \\
10 \\
4\end{array}$ & $\begin{array}{ll}5 & 1 \\
4 & -1 \\
1 & 1 \\
5 & 1 \\
8 & 1 \\
1 & 3\end{array}$ & 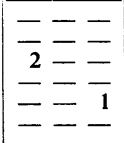 & $\begin{array}{l}0 \\
0 \\
0 \cdot 5 \\
0 \\
0 \cdot 1 \\
0\end{array}$ & $\begin{array}{r}99 \\
115 \\
103 \\
145 \\
83 \\
74\end{array}$ & $\begin{array}{rr}96 & 3 \\
107 & 6 \\
101 & 2 \\
133 & 7 \\
78 & 4 \\
70 & 2\end{array}$ & $\begin{array}{ll}\frac{-1}{1} & \frac{1}{4} \\
4 & \frac{1}{1} \\
-1\end{array}$ & $\begin{array}{l}\bar{z} \\
\bar{E} \\
1\end{array}$ & $\begin{array}{l}0 \\
0 \cdot 02 \\
0 \\
0 \cdot 04 \\
0 \cdot 01 \\
0 \cdot 03\end{array}$ & $\begin{array}{r}4 \\
5 \\
7 \\
13 \\
11 \\
10\end{array}$ & \begin{tabular}{ll|}
2 & 2 \\
5 & 2 \\
1 & 2 \\
2 & 9 \\
8 & 1 \\
4 & 2
\end{tabular} & $\begin{array}{l}--\overline{-} \\
\overline{4}-\overline{-} \\
11- \\
11- \\
4-\end{array}$ & $\begin{array}{l}0 \\
0 \\
0 \cdot 6 \\
0 \cdot 2 \\
0 \cdot 2 \\
0 \cdot 4\end{array}$ & \begin{tabular}{r|}
102 \\
101 \\
117 \\
139 \\
101 \\
80
\end{tabular} & $\begin{array}{rr}96 & 6 \\
91 & 7 \\
101 & 13 \\
118 & 19 \\
76 & 12 \\
65 & 10\end{array}$ & $\begin{array}{rrr}-\overline{3} & - & - \\
3 & - & - \\
2 & - & - \\
10 & 1 & 2 \\
1 & 3 & 1\end{array}$ & 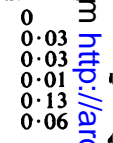 \\
\hline$\overline{\text { Total }}$ & 34 & 247 & $2-1$ & $\begin{array}{l}9 \text { per } \\
\text { cent. }\end{array}$ & 619 & 58324 & 63 & 1 & $\begin{array}{c}2 \text { per } \\
\text { cent. }\end{array}$ & 50 & 2216 & $102-$ & 24 per & 640 & $\overline { 5 4 7 } \longdiv { 6 7 }$ & $\begin{array}{lll}1943\end{array}$ & 4 per $\frac{\theta}{\sigma}$ \\
\hline \multicolumn{4}{|c|}{ Equivalent Average Morbidity } & 10 & & & & & 2 & & & & 22 & & & & 4 \\
\hline
\end{tabular}

TABLE IV

RADIOLOGICAL RESIDUA IN PERSONS WITH AND WITHOUT A PAST HISTORY OF POLYARTHRITIS, BY SEX

\begin{tabular}{|c|c|c|c|c|c|c|c|c|c|c|c|c|c|c|c|c|}
\hline \multirow{3}{*}{ Residua } & \multicolumn{8}{|c|}{ Males } & \multicolumn{8}{|c|}{ Females } \\
\hline & \multicolumn{4}{|c|}{ Past Polyarthritis } & \multicolumn{4}{|c|}{ No Past Polyarthritis } & \multicolumn{4}{|c|}{ Past Polyarthritis } & \multicolumn{4}{|c|}{ No Past Polyarthritis } \\
\hline & Total & 01 & $\begin{array}{lllll}2 & 3 & 4 & \text { N S }\end{array}$ & $\begin{array}{c}\text { Per- } \\
\text { centage } \\
\text { Grade } \\
2-4 \\
\end{array}$ & Total & $\begin{array}{ll}0 & 1\end{array}$ & 2334 N.S. & $\begin{array}{c}\text { Per- } \\
\text { centage } \\
\text { Grade } \\
2-4\end{array}$ & Total & 01 & $2 \begin{array}{lllll}2 & 3 & 4 & \text { N.S. }\end{array}$ & $\begin{array}{c}\text { Per- } \\
\text { centage } \\
\text { Grade } \\
2-4\end{array}$ & Total & $\begin{array}{ll}0 & 1\end{array}$ & $\begin{array}{lllll}2 & 3 & 4 & \text { N.S. }\end{array}$ & $\begin{array}{l}\text { Eer- } \\
\text { centag } \\
\text { Gqad } \\
\frac{5}{\bar{D}} 4 \\
0\end{array}$ \\
\hline $\begin{array}{l}\text { Hands } \\
\text { and Feet } \\
\text { Cervical .. }\end{array}$ & $\begin{array}{l}34 \\
34\end{array}$ & $\begin{array}{ll}27 & 6 \\
28 & 1\end{array}$ & $\begin{array}{llll}1 & 0 & 0 & 0 \\
3 & 0 & 0 & \end{array}$ & $\begin{array}{l}3 \\
9\end{array}$ & $\begin{array}{l}619 \\
619\end{array}$ & $\begin{array}{rr}513 & 68 \\
472 & 100\end{array}$ & $\begin{array}{llll}13 & 4 & 0 & 21 \\
19 & 1 & 0 & 26\end{array}$ & $\begin{array}{l}\mathbf{3} \\
\mathbf{3}\end{array}$ & $\begin{array}{l}50 \\
50\end{array}$ & $\begin{array}{l}389 \\
359\end{array}$ & $\begin{array}{lllll}2 & 0 & 0 & & 1 \\
5 & 0 & 0 & & 1\end{array}$ & $\begin{array}{r}4 \\
10\end{array}$ & $\begin{array}{l}640 \\
640\end{array}$ & $\begin{array}{l}51286 \\
48790\end{array}$ & $\begin{array}{llll}11 & 1 & 3 & 27 \\
21 & 4 & 0 & 38\end{array}$ & $\frac{1}{0}$ \\
\hline
\end{tabular}




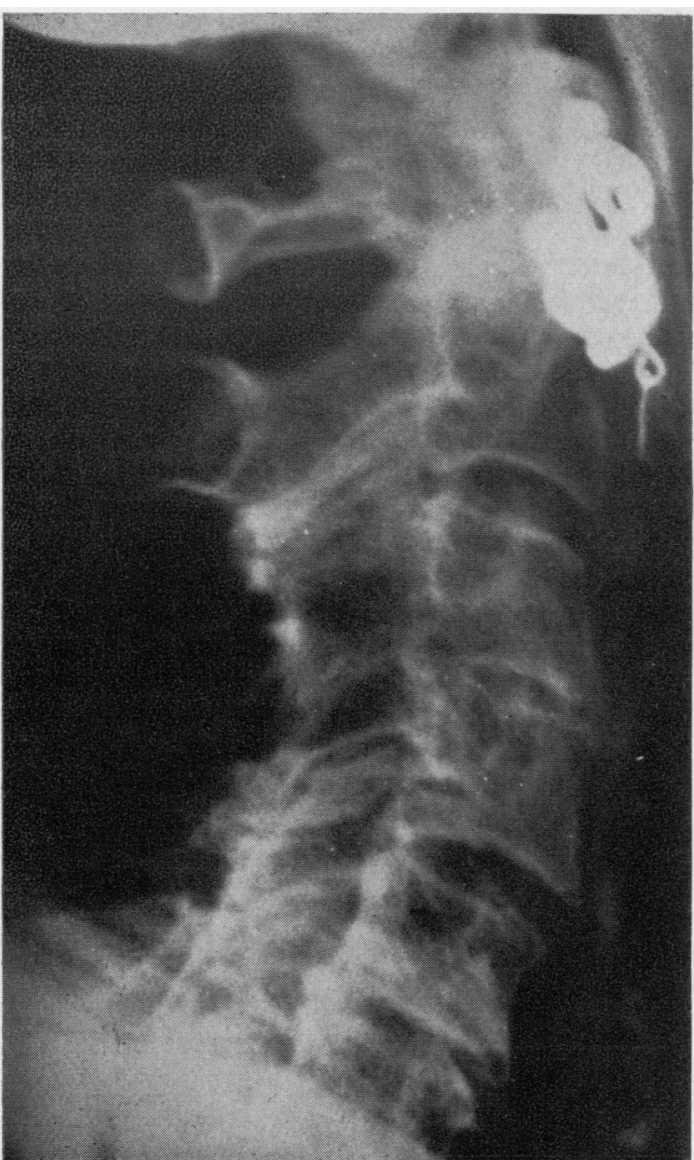

Fig. 1.-Cervical spine in female aged 77 with past history of polyarthritis. Ankylosis of apophyseal joint C.3-4 with narrowing of disk.

Sheep-cell Agglutination Test.-The sheep-cell test (Table V) was positive in two males (6 per cent.) and four females ( 9 per cent.) with a past history of polyarthritis. This may be compared with figures of 5 and 6 per cent. in males and females without such a history. Neither of these differences is significant. A study of the titre distribution shows

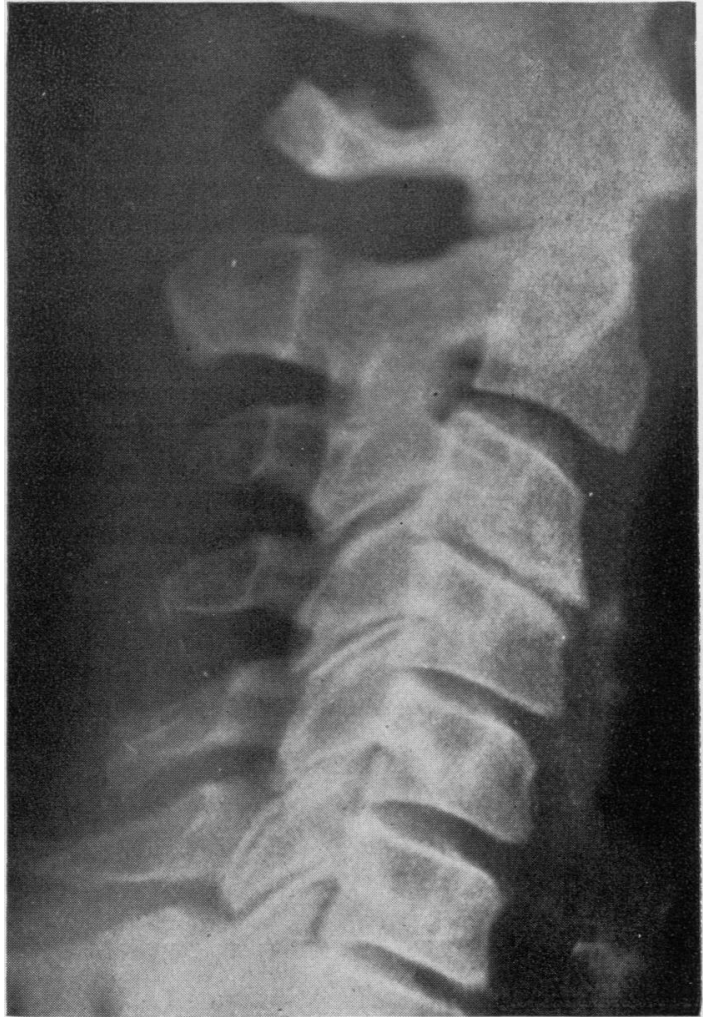

Fig. 2.-Cervical spine in male aged 65 with past history of polyarthritis. Narrowing of disk C.3-4 with proliferation. Anterior subluxation at disk C.2-3 and posterior subluxation at disks C.3-4 and 4-5.

that three of the four females with a history of polyarthritis and a positive sheep-cell test had a titre of 1 in 64 or over, whereas only one-third of the sero-positive females without polyarthritis had such a high titre. This difference, however, is also not significant and in males the reverse holds, there being no positive titres above 1 in 32 in those with a past history of polyarthritis. Of the four seropositive females, three had clinical residua, the fourth gave a history of pain and swelling of her knees

TABLE V

SHEEP-CELL AGGLUTINATION TITRE IN PERSONS WITH AND WITHOUT PAST HISTORY OF POLYARTHRITIS, BY SEX

\begin{tabular}{|c|c|c|c|c|c|c|c|c|c|c|c|c|c|}
\hline Sex & Total & S.C.A.T. Titre & 0 & 4 & 8 & 16 & 32 & 64 & 128 & 256 & 512 & $\begin{array}{l}\text { Not } \\
\text { Tested }\end{array}$ & $\begin{array}{l}\text { Percentage } \\
32 \text { and Over }\end{array}$ \\
\hline Male & $\begin{array}{r}34 \\
619\end{array}$ & $\begin{array}{l}\text { Past Polyarthritis } \\
\text { No Past Polyarthritis }\end{array}$ & $\begin{array}{r}18 \\
363\end{array}$ & 111 & $\begin{array}{r}6 \\
62\end{array}$ & $\begin{array}{r}2 \\
30\end{array}$ & $\begin{array}{r}2 \\
12\end{array}$ & $\begin{array}{l}0 \\
8\end{array}$ & $\begin{array}{l}0 \\
7\end{array}$ & $\begin{array}{l}0 \\
3\end{array}$ & $\begin{array}{l}0 \\
1\end{array}$ & $\begin{array}{r}1 \\
22\end{array}$ & $\begin{array}{l}6 \\
5\end{array}$ \\
\hline Female & $\begin{array}{r}50 \\
640\end{array}$ & $\begin{array}{l}\text { Past Polyarthritis } \\
\text { No Past Polyarthritis }\end{array}$ & $\begin{array}{r}26 \\
339\end{array}$ & $\begin{array}{r}7 \\
108\end{array}$ & $\begin{array}{r}6 \\
72\end{array}$ & $\begin{array}{r}3 \\
41\end{array}$ & 22 & $\begin{array}{l}1 \\
3\end{array}$ & $\begin{array}{l}0 \\
6\end{array}$ & $\begin{array}{l}2 \\
1\end{array}$ & $\begin{array}{l}0 \\
1\end{array}$ & $\begin{array}{r}4 \\
47\end{array}$ & $\begin{array}{l}9 \\
6\end{array}$ \\
\hline
\end{tabular}


3 months previously. She refused to allow a clinical examination of her knees or feet but had no clinical evidence of the disease elsewhere. The two males with a positive test both had radiological evidence of erosive arthritis in the cervical spine but neither had definite clinical residua.

Cardiac Residua.-A history of cardiac involvement at the time of the attack was given by seven males and seven females (17 per cent.), but only four of these (two males and two females) had clinical evidence of mitral stenosis in the form of an apical presystolic murmur. In none was there evidence of aortic involvement. One patient had auricular fibrillation but was hypertensive, another an apical systolic murmur with slight prominence of the pulmonary conus on $x$ ray and may possibly have had mitral valvular disease with regurgitation.

A chest $x$ ray was made in 22 of the males and 23 of the females with a history of polyarthritis. Only one of those with mitral stenosis was able to attend for chest $x$ ray but in this one the diagnosis was confirmed. No other showed evidence of mitral disease on $x$ ray.

Enlargement of the left ventricle was noted in two males and one female. Only the female had a raised blood pressure. In the two males no cause for the left ventricular enlargement was found.

Age at Onset.-In both sexes the onset was most frequent between the ages of 5 and 24 , some 60 per cent. arising between these ages (Table VI). In only one did the attack start before age 5, actually at age 3 . After age 24, the incidence fell sharply, and in only nine (11 per cent.) did the condition appear after age 44 . This variation in age incidence is partly but not wholly, due to the smaller numbers in whom the disease could have occurred in later decades. The age distribution is in general that of rheumatic fever. Those with residua tended to have their onset rather later in life, some 50 per cent. appearing between the ages of 5 and 24 and 20 per cent. after age 44. Those with cardiac residua on the other hand all had their attack between the ages of 5 and 24.

Season of Onset.-Of the 84 persons with a history of past polyarthritis, 25 were unable to remember at what season the attack arose. Eleven were able only to remember whether the attack occurred in winter, spring, summer, or autumn, but the remainder could recall within a month or two the date of onset. In this last group, the illness started most commonly between. January and March and least often between May and August (Fig. 3, opposite). Those with residua had a less striking seasonal incidence than the remainder.

The monthly incidence indicates a rather earlier onset than in rheumatic fever (as shown by the data of Coburn and Young, 1949), in which the maximum is attained in March and the minimum in September (Fig. 3). It does, however, fit remarkably closely the data given by Short, Bauer, and Reynolds (1957) for exacerbation of rheumatoid arthritis.

Year of Onset.-A study of the years in which these attacks occurred has been made and is shown in Table VII (overleaf). Only those attacks starting before 1954, when the survey started, are includedo The first attack occurred in 1885, the last in 1954They were fairly evenly distributed over the interven ing years, the largest number in any one year being four. The condition thus appeared to be endemic rather than epidemic. The highest proportion ( 3 per cent. of those living at that time) was found in the 1905 to 1914 decade. There was no evidence that the condition is becoming less frequent though its nature appears to be changing. Those with mitral stenosis all had had their attack of polyarthritis before 1918 and, of those with a history of heart

TABLE VI

AGE AT ONSET OF POLYARTHRITIS, BY SEX

\begin{tabular}{|c|c|c|c|c|c|c|c|c|c|c|}
\hline \multirow{4}{*}{$\begin{array}{c}\text { Age at } \\
\text { Onset } \\
\text { (yrs) }\end{array}$} & \multicolumn{3}{|c|}{ Males } & \multicolumn{3}{|c|}{ Females } & \multicolumn{4}{|c|}{ Both Sexes } \\
\hline & \multirow{3}{*}{$\begin{array}{c}\text { Total } \\
\text { Liable }\end{array}$} & \multicolumn{2}{|c|}{ Past Polyarthritis } & \multirow{3}{*}{$\begin{array}{c}\text { Total } \\
\text { Liable }\end{array}$} & \multicolumn{2}{|c|}{ Past Polyarthritis } & \multicolumn{4}{|c|}{ Past Polyarthritis } \\
\hline & & \multirow{2}{*}{ Total } & \multirow{2}{*}{ With Residua } & & \multirow{2}{*}{ Total } & \multirow{2}{*}{ With Residua } & \multicolumn{2}{|c|}{ Total } & \multicolumn{2}{|c|}{ With Residua } \\
\hline & & & & & & & No. & Per cent. & No. & Per cent. \\
\hline $\begin{array}{l}-4 \\
-14 \\
-24 \\
-34 \\
-44 \\
-54 \\
-64 \\
65+\end{array}$ & $\begin{array}{r}653 \\
653 \\
653 \\
548 \\
429 \\
322 \\
171 \\
78\end{array}$ & $\begin{array}{r}0 \\
11 \\
11 \\
5 \\
3 \\
2 \\
2 \\
0\end{array}$ & $\begin{array}{l}0 \\
2 \\
1 \\
1 \\
2 \\
0 \\
1 \\
0\end{array}$ & $\begin{array}{r}690 \\
690 \\
690 \\
584 \\
478 \\
354 \\
202 \\
90\end{array}$ & $\begin{array}{r}1 \\
16 \\
15 \\
7 \\
6 \\
4 \\
1 \\
0\end{array}$ & $\begin{array}{l}0 \\
4 \\
4 \\
2 \\
1 \\
3 \\
1 \\
0\end{array}$ & $\begin{array}{r}1 \\
27 \\
26 \\
12 \\
9 \\
6 \\
3 \\
0\end{array}$ & $\begin{array}{l}0 \cdot 07 \\
2 \\
2 \\
1 \\
0 \cdot 9 \\
0 \cdot 9 \\
0 \cdot 8 \\
0\end{array}$ & $\begin{array}{l}0 \\
6 \\
5 \\
3 \\
3 \\
3 \\
2 \\
0\end{array}$ & $\begin{array}{l}0 \\
0.4 \\
0.4 \\
0.3 \\
0.3 \\
0.4 \\
0.6 \\
0\end{array}$ \\
\hline Total & & 34 & 7 & & 50 & 15 & 84 & & 22 & \\
\hline
\end{tabular}



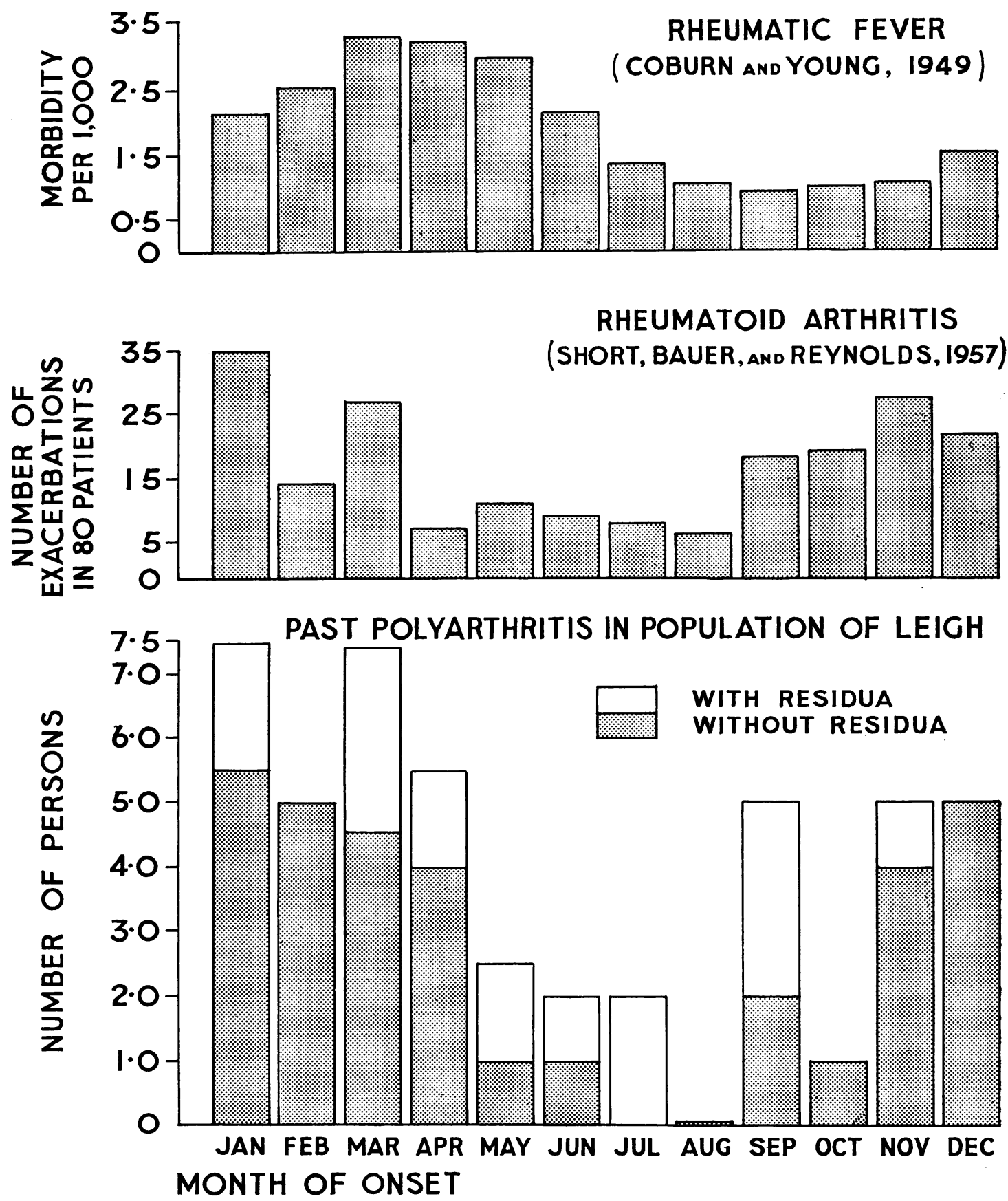

Fig. 3.-Season of onset of rheumatic fever, rheumatoid arthritis, and benign polyarthritis. 
TABLE VII

YEAR OF ONSET OF POLYARTHRITIS

\begin{tabular}{|c|c|c|c|c|c|c|c|c|c|}
\hline \multirow{4}{*}{ Year of Onset } & \multirow{4}{*}{ Total Available } & \multicolumn{8}{|c|}{ Past Polyarthritis } \\
\hline & & \multirow{2}{*}{\multicolumn{2}{|c|}{ Total }} & \multicolumn{4}{|c|}{ With Rheumatic Heart Disease } & \multirow{2}{*}{\multicolumn{2}{|c|}{$\begin{array}{l}\text { With } \\
\text { Arthritic } \\
\text { Residua }\end{array}$}} \\
\hline & & & & \multicolumn{2}{|c|}{ History Only } & \multicolumn{2}{|c|}{ Mitral Stenosis } & & \\
\hline & & No. & Per cent. & No. & Per cent. & No. & Per cent. & No. & Per cent. \\
\hline $\begin{array}{r}1885-1904 \\
-1914 \\
-1924 \\
-1934 \\
-1944 \\
-1954\end{array}$ & $\begin{array}{r}373 \\
676 \\
907 \\
1,132 \\
1,343 \\
1,343\end{array}$ & $\begin{array}{l}2 \\
18 \\
12 \\
16 \\
18 \\
16\end{array}$ & $\begin{array}{l}0 \cdot 5 \\
2 \cdot 7 \\
1 \cdot 3 \\
1 \cdot 4 \\
1 \cdot 3 \\
1 \cdot 2\end{array}$ & $\begin{array}{l}2 \\
4 \\
2 \\
4 \\
1 \\
0\end{array}$ & $\begin{array}{l}0.5 \\
0.6 \\
0.2 \\
0.4 \\
0.07 \\
0\end{array}$ & $\begin{array}{l}1 \\
1 \\
2 \\
0 \\
0 \\
0\end{array}$ & $\begin{array}{l}0 \cdot 3 \\
0 \cdot 1 \\
0 \cdot 2 \\
0 \\
0 \\
0\end{array}$ & $\begin{array}{l}2 \\
3 \\
4 \\
7 \\
4 \\
2\end{array}$ & $\begin{array}{l}0.5 \\
0.4 \\
0 \cdot 4 \\
0 \cdot 6 \\
0 \cdot 4 \\
0 \cdot 1\end{array}$ \\
\hline
\end{tabular}

involvement, only one had his attack after 1934 . The number of persons with polyarthritis associated with arthritic residua remained fairly constant except in those whose attacks occurred after 1944, of whom only two had arthritic residua. This may be because residua have not become apparent for example on $x$ ray particularly in the spine. It would seem unlikely that this could explain the lower prevalence of cardiac residua in the more recent attacks.

Association with Other Rheumatic Diseases.-The possibility that this type of polyarthritis might produce a tendency to degenerative joint disease later, has been considered. Of the 34 males with past history of polyarthritis, three (14 per cent.) were found to have osteo-arthrosis in four or more groups of joints* compared with 59 (10 per cent.) in the remainder of the males. For the females, the figures were fourteen ( 25 per cent.) and 88 (14 per cent.) respectively. When these figures were corrected for age, the differences were much reduced, 13 and 12 per cent. respectively for males and 21 and 16 per cent. for females. Thus there is no significant increase in osteo-arthrosis in later life in persons with a history of polyarthritis though there may be a slight predisposition in females.

No significant increase was found in the amount of intervertebral disk degeneration in persons with a history of polyarthritis, though there was a tendency towards more frequent involvement of cervical and dorsal disks in males and of lumbar disks in females.

Regional Prevalence.-In addition to the population of Leigh, other populations have been examined, notably in Wensleydale and in the Rhondda Fach and Vale of Glamorgan in South Wales. Only in Wensleydale have all age groups been examined,

\footnotetext{
* For this purpose all distal interphalangeal joints of the fingers,
} for example, were considered as one. and here the proportion of persons who had had $\overrightarrow{\vec{\omega}}$ an attack of polyarthritis was very similar to that found in Leigh, 6 per cent in males and 8 per cent. $\frac{0}{2}$ in females (Table VIII). In South Wales the prevalence was 6 and 12 per cent. respectively. Only the 55 to 64 age group was examined in the is females in South Wales and the figure was thus very similar to the 10 and 12 per cent. prevalence in Leigh and Wensleydale in females in this age $\vec{z}$ group.

TABLE VIII

PAST POLYARTHRITIS IN DIFFERENT AREAS, BY SEX

\begin{tabular}{|c|c|c|c|c|c|c|}
\hline \multirow{3}{*}{ Area } & \multicolumn{3}{|c|}{ Males } & \multicolumn{3}{|c|}{ Females } \\
\hline & \multirow{2}{*}{ Total } & \multicolumn{2}{|c|}{ Polyarthritic } & \multirow{2}{*}{ Total } & \multicolumn{2}{|c|}{ Polyarthritie } \\
\hline & & No. & Per cent. & & No. & Per cent. \\
\hline $\begin{array}{l}\text { Leigh } \\
\text { Wensleydale } \\
\text { South Wales }\end{array}$ & $\begin{array}{l}653 \\
393 \\
527\end{array}$ & $\begin{array}{l}34 \\
22 \\
34\end{array}$ & $\begin{array}{l}5 \\
6 \\
6\end{array}$ & $\begin{array}{l}690 \\
479 \\
268\end{array}$ & $\begin{array}{l}50 \\
39 \\
33\end{array}$ & $\begin{array}{r}7 \\
8 \\
12\end{array}$ \\
\hline
\end{tabular}

\section{Discussion}

In the past, it has been customary to include all acute self-limiting polyarthritis under the category of rheumatic fever and no doubt in most instances 3 . this was correct. It was, however, recognized that in a few cases classical rheumatoid arthritis sub- $\frac{3}{3}$ sequently developed. It is probably true today that $\mathrm{O}$ most of the patients admitted to hospital with acute febrile polyarthritis are in fact cases of rheumatic $\frac{7}{0}$ fever.

Cardiac abnormalities have been found in from $N$ 51 to 74 per cent. of patients having rheumatic $N$ fever in childhood though in only 17 to 24 per cent. N of those attacked in adult life (Engleman, Hollister,
and Kolb, 1954).

Patients in the present series were almost all $\stackrel{0}{ᄃ}$ treated at home and, therefore, presumably included $\stackrel{\Phi}{\Phi}$ many milder forms not commonly seen in hospital ${ }_{-}^{-}$ practice. This might account for the low pre- 
valence of cardiac abnormalities. Moreover, a certain number of persons who had rheumatic fever in the households under review will have died before 1954, and will thus have been omitted from the survey. It is impossible to know how many were excluded in this way. In a series of 1,000 cases of rheumatic fever followed for 10 years (Schlesinger, 1938), 12 per cent. had died, the mortality falling off rapidly after age 14 . From the Registrar General's figures for 1940-49, it would be expected that some eighteen persons would have died in a population sample of the size used in this study over the period of 70 years which it covers. Thus the original sample might have been 102 of whom 22 developed heart disease and eighteen died.

Arthritic residua were found in 23 of the 84 survivors and it would thus appear that at least as many of the original cases developed arthritic as cardiac residua. This proportion is likely to be changing however. Admissions to Great Ormond Street Hospital for acute rheumatism have fallen from 216 to 25 in the last 50 years (Sheldon, 1958). The Registrar General's figures for England and Wales, moreover, show a steady decline in mortality from rheumatic fever from 1,251 in 1940 to 208 in 1956 , and a similar reduction is occurring in other countries (Southwood, 1959). The figures shown in Table VII indicate that there is a corresponding reduction in the proportion of attacks of polyarthritis which are associated with cardiac complications and it may well be that almost as many attacks occurring at the present time in the population are not rheumatic fever but belong to some relatively benign form of polyarthritis.

What is the nature of this condition? The onset is commonly between the ages of 5 and 24 . It is only slightly commoner in females. Attacks occur chiefly between January and March. The attack is usually single, but as many as nine attacks have occurred in one person. As would be expected, residua are more common in those who have had repeated attacks. The attack commonly lasts 2 to 3 months but some patients have been away from school or work for over a year. On the other hand twelve (14 per cent.) were able to continue their occupation throughout.

Because of the lapse of time, it was often difficult to elicit a detailed account of the illness. A prodromal throat infection was remembered by only a few. Many recalled only having pain all over and sweating profusely. A common sequence, however, was pain which started in the feet and spread to the ankles and knees and sometimes to the hands with or without joint swelling. Often the upper extremities had apparently remained quite unaffected.
Severe pain in the back, neck, and shoulders was often mentioned in addition to peripheral pain.

Several possibilities must be considered in discussing the nature of this benign form of polyarthritis. The age at onset and the rheumatoid nature of the arthritic residua suggests that many would fall into the category of Still's disease, a diagnosis which cannot be altogether excluded by the favourable outcome. In the series of 200 cases of Still's disease followed by Ansell and Bywaters (1959), the disease became inactive in 95 , and in 44 per cent. of early cases there were no joint residua. As in the present cases, the cervical spine has been found to be a frequent site of radiological change, but the diminished width of vertebral bodies commonly found in patients who have had Still's disease was not seen in the present series and the acute course of the polyarthritis is not typical.

Many of those in whom the condition occurred in adult life would, in the less acute forms, have been diagnosed as cases of rheumatoid arthritis. The relatively benign course of adult polyarthritis in which the sheep-cell test is negative has been stressed by Duthie, Brown, Knox, and Thompson (1957). It cannot be known what the sheep-cell titre may have been at the time of the attack in the present series. In some instances the test is known to change from positive to negative in rheumatoid patients. In others, however, the change is in the reverse direction. Had an appreciable proportion of patients in the present series been sheep-cell positive during the attack, there would surely have been a significantly higher proportion of positives in the polyarthritics than in the remainder of the population.

The joint residua found in these patients do not resemble those described by Jaccoud (1869), Bach (1935), and Bywaters (1950) in patients with rheumatic heart disease. The predominant involvement of the metacarpophalangeal joints of the hands with ulnar deviation and hook erosions was not seen in these patients. Moreover, these changes are usually considered to be rare, even in patients who have had a severe attack of rheumatic fever.

Attacks of polyarthritis have been noted by Hollister and Engleman (1958) as a frequent precursor of spondylitis. As no patients in this series. later developed spondylitis this would not seem to be a likely explanation.

Leu (1954) has described a condition which he has labelled "abortive acute polyarthritis". This condition appeared in the early months of the year but was otherwise unlike the present series, constitutional upset being slight and the temperature 
normal. Some may, however, have belonged to this category.

The polyarthritis described in this paper bears no resemblance to palindromic rheumatism, in which the arthritis is more transient and commonly affects only one joint at a time, but many would fall into the category of "subacute" rheumatism described by Newman (1924) in his survey of rheumatic diseases. Three females and two males gave a history of skin lesions consistent with a diagnosis of erythema nodosum: Only one of these had joint residua and in this person the sheep-cell test was strongly positive.

No definite views on causation can be expressed on the evidence available. The seasonal onset would suggest that, in some individuals, attacks of this kind may be related to one or more of the infectious diseases which are prevalent in the first 3 months of the year. The similarity between the seasonal onset of benign polyarthritis and of exacerbations of rheumatoid arthritis further suggest that the same infections may trigger the rheumatoid exacerbation in persons so predisposed.

In clinical experience, benign forms of polyarthritis are not uncommonly associated with viral diseases. Polyarthritis occurring as a complication in epidemics of rubella has been described by Geiger (1918), Hope Simpson (1940), Bennett and Copeman (1940), Loudon (1953), and Lewis (1954). A notable feature is that adults are mainly affected, females more than males, and that the attack is often associated with eye symptoms-redness, photophobia, and lacrimation. According to Johnson and Hall (1958), the latex test is negative on whole serum, but a positive inhibition test is found in nine out of ten patients with rubella arthritis. Lloyd (personal communication) has encountered several cases of arthritis occurring in an epidemic of measles, and it has also been observed in infective hepatitis.

\section{Summary}

During a survey of rheumatic disease in a random population sample of persons aged 15 years and over in the town of Leigh, 5 per cent. of males and 7 per cent. of females gave a past history of one or more attacks of polyarthritis.

Of the 84 persons giving such a history, only four had definite clinical or radiological evidence of rheumatic heart disease, but 23 had joint residua. Both clinically and radiologically, these patients had more evidence of inflammatory joint residua than the remainder of the population, but the sheep-cell agglutination test was positive in only 7 per cent.
Radiological changes were found chiefly in the 꾹 cervical spine and resembled, but were not typical $\underset{\mathbb{\Phi}}{\overparen{D}}$ of, those found in rheumatoid arthritis.

Attacks were most frequent in the winter months $\underline{\underline{ }}$. and were sometimes recurrent. The onset was? commonly between the ages of 5 and 24 , but might $\underset{\vec{N}}{\vec{F}}$ occur at any age, the oldest patient being 63 years old. Patients were seldom admitted to hospital.

It is suggested that many cases of acute and sub- $\frac{\bar{\sigma}}{\frac{5}{b}}$ acute rheumatism fall into a category of benign $\vec{\Phi}$ polyarthritis related to the sheep-cell negative group $\frac{2}{0}$
of inflammatory polyarthritis.

We are indebted to Professor J. H. Kellgren for his $\overrightarrow{\vec{Z}}$ advice and to Dr. J. Ball for estimating the sheep-cell test. $\stackrel{\omega}{\Delta}$

\section{REFERENCES}

Ansell, B. M., and Bywaters, E. G. L. (1959). Bull. rheum. Dis., Bach, F. (1935). "The Rheumatic Diseases," p. 90. Cassell, London.

Ball, J. (1950). Lancet, 2, 520.

Bennett, R. A., and Copeman, W. S. C. (1940). Brit. med. J., 1, 924. Bennett, R. A., and Copeman, W. S. C. (1940). Brit. med. J., 1, 924. -
Bywaters, E. G. L. (1950). Brit. Heart J., 12,101.
Coburn, A. F., and Young, D. C. (1949). "The Epidemiology of
Hemolytic Streptococcus during World War II in the United Hemolytic Streptococcus during World War II in the United

Duthie, J. J. R., Brown, P. E., Knox, J. D. E., and Thompson, M.

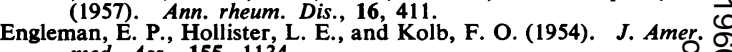
med. Ass., 155, 1134.

Geiger, J. C. (1918). Ibid., 70, 1818.

Hollister, L. E., and Engleman, E. P. (1958). J. chron. Dis., 8, 38

Hope Simpson, A. E. (1940). Brit. med. J., 1, 830.

Jaccoud, S. (1869). "Leçons de clinique médicale faites à l'Hôpíğ de la Charite," 2nd edition, p. 598. Delahaye, Paris.

Johnson, R. E., and Hall, A. P. (1958). New Engl. J. Med., 258, 743. 은 Kellgren, J. H., and Lawrence, J. S. (1956). Ann. rheum. Dis., 15, 1. 尺े Leu, H. J. (1954). Praxis, 43, 913.

Lewis, G. W. (1954). Rheumatism, 10, 66.

Loudon, I. S. L. (1953). Brit. med. J., 1, 1388. Loudon, I. S. L. (1953) Minitry of Health Reports on Public Health $\overrightarrow{\vec{O}}$
Newman, G. (1924). Mind Medical Subjects, No. 23. H M.S.O., London.

Schlesinger, B. (1938). Lancet, 1, 593.

Sharp, J., Purser, D. W., and Lawrence, J. S. (1958). Ann. rheum. Dis., 17, 303 .

Sheldon, W. (1958). Med. Ann., p. 40.

Short, C. L., Bauer, W., and Reynolds, W. E. (1957). "Rheumatoid Arthritis." Harvard University Press, Cambridge, Mass. Southwood, A. R. (1959). Lancet, 1, 377.

\section{DISCUSSION}

DR. W. R. M. AlEXANDER (Edinburgh) asked whether 을 there was any history of erythema nodosum in these $>$ patients, and secondly, although the sheep cell test was negative at the time of the survey, whether the author could be certain that it was negative at the time of the $N$ polyarthritis? Some patients with acute polyarthritis N might have a positive sheep cell test which later became negative.

DR. H. F. West (Sheffield) said that it was his impres- -0 sion that this was a familiar picture. The patients $\Phi$ arrived after about one month, with a history of an $\stackrel{?}{+}$ upper respiratory infection. After returning to work $\square$ they had developed an acute polyarthritis. They were $\bar{D}$ 
usually young adults and the chances were that the arthritis would clear within 6 months. Their hearts were examined and an attempt was made to assess whether they were to be treated as cases of rheumatic fever and whether they needed a strict regimen of rest in bed.

DR. K. Lloyd (Cardiff) said that about 4 years earlier he had seen many cases of acute polyarthritis developing about the tenth day of measles, lasting for 3 or 4 weeks, and leaving no residua. He did not know whether there had been any other unusual features of the measles epidemic that year, or to what extent there might be a link between the higher rate of illness in winter and spring and cases of polyarthritis with no residua.

Prof. E. G. L. Bywaters (London) said that he used to call this condition "doctors' wives' syndrome", because the cases presented early. It was not a single syndrome, but most types of arthritis had abortive specimens among them, which might abort within a day or two of the onset. It was not possible to define these fleeting polyarthritic attacks very closely as they might easily fit a variety of conditions. He asked whether the sacro-iliac joints showed any changes.

DR. O. Savage (London) said that the condition was not uncommon, and that a negative Rose-Waaler test was often seen in rheumatoid arthritis of less than one year's duration.

DR. M. Thompson (Newcastle-upon-Tyne) recalled that Dr. Lloyd had mentioned polyarthritis complicating measles. A similar state of affairs was sometimes seen with German measles, especially in adult females, and polyarthritis might also be seen during and after infective hepatitis. There appeared to be many types of selflimited polyarthritis, some associated with virus infections. The ultimate answers to the definition of these various forms of acute polyarthritis would only come from prospective studies. The current study of 1,000 families in Newcastle-upon-Tyne, concerned with infants born in 1947 and 1948, might give some information of value although the numbers were small for this type of study.

DR. J. J. R. DuthIE (Edinburgh) said that he had had some forty cases of this type but, far from being mild, they were so acute that all the patients concerned were admitted to hospital within the first year of their illness. Initially they all looked as if they were going rapidly downhill, but as they had a good prognosis they should not necessarily be treated with steroids.

Prof. S. J. Hartfall (Leeds) observed that there had been no information about throat infections or streptococci.

DR. LAWRENCE replied that they had had five patients with a history of erythema nodosum. The sheep cell test might become negative in a recovering polyarthritis but in just as many cases it became more positive. When he had studied the population he had found an increasing prevalence of positive tests with age. $\mathrm{He}$ thought that if many of these people had had positive tests at the time of their polyarthritis, they would have afterwards found a greater prevalence of positive tests among them than in the rest of the population.

Attacks following measles are interesting but none of the patients in this study had volunteered a history of measles, although some said they had had a sore throat. He agreed that this was not a single syndrome. The sacro-iliac joints were only $x$-rayed in the older age groups, and no striking changes had been seen in those done. With regard to the streptococcus, only a few gave a history of preceding sore throat, but the seasonal incidence had corresponded roughly with that of streptococcal infection.

Prof. J. H. Kellgren (Manchester) said that the condition described was common, and apparently involved 5 per cent. of the population, yet little had been written about it. He thought it interesting that very few patients had subsequently developed chronic polyarthritis. The whole subject of polyarthritis in relation to virus diseases was something they should know more about, and he was hoping that members of the society would collect more data.

\section{Polyarthrite benigne}

\section{RÉSUMÉ}

Au cours d'une enquête sur la maladie rhumatismale, effectuée sur une population d'essai de la ville de Leigh, comprenant des personnes âgées de 15 ans et plus, on trouva que $5 \%$ d'hommes et $7 \%$ de femmes eurent des antécédants d'une attaque au moins de polyarthrite.

Sur 84 personnes avec ces antécédants, quatre seulement présentèrent des signes cliniques et radiologiques définis de cardiopathie rhumatismale, mais 23 personnes eurent des séquelles articulaires. Du point de vue clinique et radiologique, ces personnes présentèrent plus de signes de séquelles inflammatoires articulaires que le reste de la population, mais la réaction d'agglutination des globules rouges de mouton ne fut positive qu'en $7 \%$ d'entre elles. Les altérations radiologiques se trouvèrent surtout dans la colonne cervicale et ressemblèrent, sans être typiques, à celles trouvées dans l'arthrite rhumatismale.

Les attaques survenaient le plus souvent en hiver et quelquefois tendaient à revenir. La maladie commençait généralement entre les âges de 5 à 24 ans, mais pouvait commencer à n'importe quel âge, le malade le plus vieux étant âgé de 63 ans. Admission à l'hôpital était rarement nécessaire.

On suggère que beaucoup de cas de rhumatisme aigu et subaigu appartiennent à la catégorie de polyarthrite benigne, associée au groupz de polyarthrite inflammatoire à réaction d'agglutination des globules rouges de mouton négative.

\section{Poliartritis benigna}

\section{SUMARIO}

En el curso de investigación sobre enfermedad reumática, realizada en una muestra de población no seleccionada de personas de edad superior a 15 años, en la ciudad de Leigh, se encontró que el $5 \%$ de los varones y el 7\% de las mujeres referían uno o más ataques anteriores de poliartritis.

De las 84 personas con tal historia, sólo en cuatro 
existían signos evidentes, clinícos y radiológicos, de cardiopatía reumática, pero 23 tenían secuelas articulares. Clínica y radiológicamente, estos enfermos presentaban más signos de secuelas inflamatorias articulares que el resto de la población, pero la reacción de aglutinación de los eritrocitos de carnero fué positiva sólo en el 7 por ciento. Las alteraciones radiológicas aparecieron principalmente en la columna cervical y se asemejaron, sin ser típicas, a las que se encuentran en la artritis reumatoide. Los ataques aparecieron con más frecuencia durante los meses de invierno y fueron recurrentes en algunos casos. La enfermedad solia principiar entre los 5 y los 24 años, pero podía aparecer en cualquier edad, en un caso a los 63 años. Rara vez los enfermos necesitaron hospitalización.

Todo ello sugiere que muchos casos de reumatismo agudo y subagudo entran en la categoria de poliartritis $\Rightarrow$ benigna. entidad relacionada con el grupo de poliartritis inflamatoria con la reacción de aglutinación de los eritrocitos de carnero negativa. 